\title{
THE POTENTIALS OF HONEY IN MANAGING BREAST CANCER WOUNDS: A LITERATURE REVIEW
}

\section{ATLASTIEKA PRAPTIWI*}

Department of Fundamental Nursing, Faculty of Nursing, Universitas Padjadjaran, Indonesia. Email: a.praptiwi@unpad.ac.id

Received: 1 November 2016, Revised and Accepted: 24 January 2017

\section{ABSTRACT}

This review aimed to explore recent published literature, research and practice in managing breast cancer wounds with a specific focus on the potential values of honey in managing the wounds. About 10 databases were searched (CINAHL, EBSCOhost, ProQuest, Google Scholar, Wiley Interscience, Science Direct, Blackwell Synergy, Liebert Online, Internurse, and Gale Cengage) using the search terms "fungating wound" OR "malignant wound," "breast cancer wounds" AND "honey" AND “Indonesia." The search was limited from period of 2006 to 2016 , to English and Indonesian language, and only full text articles were included in the study. Reference lists of relevant articles were also hand searched. The search identified 12 articles that met the search criteria. An article published before 2006 was also included on the basis of its relevance. All articles were written in English. Publications have indicated that a malignant wound represents a cluster of symptoms such as malodor, heavy exudate, pain, bleeding, and various psychosocial issues. To stabilize and prevent wound deterioration, the physical and bioactive properties of honey may have potentials to be applied as a single treatment in primary wound dressings to manage offensive odor and heavy exudate. Further research to study native Indonesian honeys' properties will be beneficial to assist with practice decisions.

Keywords: Breast cancer, Fungating wounds, Honey, Wound management.

(C) 2017 The Authors. Published by Innovare Academic Sciences Pvt Ltd. This is an open access article under the CC BY license (http://creativecommons. org/licenses/by/4. 0/) DOI: http://dx.doi.org/10.22159/ajpcr.2017.v10s2.19500

\section{INTRODUCTION}

In a nearly three-decade period (1990-2014), there was a shift in the global distribution of breast cancer cases. While incidence rates still remained much higher in more developed countries, breast cancer was found to become a major health issue for women in Asia, Africa, and South America. During 2012, nearly a quarter of all breast cancer cases were diagnosed within the Asia-Pacific region, home of a third of global female population (at a rate of 30 per 100, 000), with the highest number of those occurring in China (46\%), Japan (14\%), and Indonesia (12\%) [1]. In Asia, breast cancer tends to occur at a younger age (more than $50 \%$ of the patients are under 50 -year-old) notwithstanding various levels of income of its countries [2]. In a low- and middle-income Asian country like Indonesia, about $60 \%$ of cancer patients seek for medical care when the disease is already in an advanced stage $[2,3]$.

It is mainly believed that people living with advanced or terminal-stage chronic illnesses such as cancers may develop chronic wounds even with the best nursing practice [4]. Such lesions are frequently identified as malignant wounds that commonly have occurrence in advanced cancer patients, when there are indications of infiltration and erosion through the skin by malignant tumor cells. Besides, phenotypic changes of resident cells characterize these chronic or delayed-healing wounds $[5,6]$.

There are some terms that have usually been used to illustrate these wounds, for example, "fungating malignant wounds," "ulcerating malignant wounds," or "malignant cutaneous wounds." In addition, the term "fungating wound" mostly refers to a lesion that primarily possesses a proliferative growth pattern, thus creates a nodular "fungus-shaped" or "cauliflower-shaped" lesion development. Conversely, the term "ulcerating wound" generates an appearance of a crater-like lesion. However, a mixed appearance of both proliferating and ulcerating areas may be shown in a lesion which is often confusing for nurses, so they most likely correlate the term "fungating wound" with breast cancer solely [6]. A study found that about $62 \%$ of malignant wounds developed within the breast area, even though they were not primarily originated from breast tissue [7]. Particularly, up to $25 \%$ of patients with breast cancer suffer from skin metastasis [8].
Women with advanced breast cancer are prone to having a greater risk of psychological morbidity and a wide-range of physical symptoms [9]. It is predicted that between $2 \%$ and $5 \%$ of breast cancer patients will develop a malignant wound which is an overwhelming complication that usually indicates progressive and untreatable disease with limited therapeutic options and an ominous prognosis $[2,10]$. This complexity is challenging for health practitioners, especially nurses in providing care across the cancer continuum $[11,12]$.

A recent qualitative study in Indonesia revealed that most of the breast cancer patients $(\mathrm{N}=17)$ initially opted for traditional health treatments and alternative therapies. If the initial choices were not effective, the patients would likely try the conventional therapy. Finally, the patients might have the conventional therapy in conjunction with complementary and traditional therapies [13]. The reliance on traditional healing methods may be attributable to limited access to, and high cost of, medical service, or to cultural beliefs and mistrust toward the health-care services [8]. Conversely, the majority of health professionals $(\mathrm{N}=12)$ supported conventional therapy as a single treatment. However, the health professionals expected that in the future there would be an effective therapy for breast cancer patients with less adverse effects combining conventional and complementary therapies [13].

Derived from the goals of palliative care, the essential goal of palliative wound care is to prioritize patient comfort by symptoms control and giving psychosocial support [14]. Accordingly, in low resource countries, while formal research into the efficacy of many traditional remedies is inadequate, local natural resources are frequently utilized in wound management on account of limited or unaffordable access to modern wound care products [15]. One of popular natural products used in the treatment of wounds since thousand years ago is honey. In the past few decades, there has been considerable resurgence of interest in the use of honey in wound management $[11,16]$. The purpose of this review is to explore recent literature, research and practice in managing breast cancer wounds with a specific focus on the potential values of honey in managing the wounds. 


\section{SEARCH STRATEGIES}

To explore publications providing information regarding current literature, research, and practice in managing malignant wounds for breast cancer patients, a search was conducted through 10 databases (CINAHL, EBSCOhost, ProQuest, Google Scholar, Wiley Interscience, Science Direct, Blackwell Synergy, Liebert Online, Internurse, and Gale Cengage) using the search terms "fungating wound" OR "malignant wound," "breast cancer wounds" AND "honey" AND "Indonesia." The search was limited from period of 2006 to 2016, to English and Indonesian language, and only full text articles were included in the study.

By using the above initial criteria, 15 full text articles were found to have potential in providing information related to malignant wound management in the breast cancer patients. All articles were written in English; none were in Indonesian. Afterward, 7 articles were chosen and 8 articles were not included because they were not relevant with the search aim. Subsequently, the reference lists from those 7 articles were hand searched and resulted in one potential full text article published before 2006 to be included in this review on the basis of its relevance with the search aim.

\section{RESULTS AND DISCUSSION}

Following the search strategies, 12 articles were selected. These articles were written by various professionals, including nurses, oncologists, physicians, and biochemist from different parts of the world (Australia [17-19], Brazil [20], Denmark [21,22], New Zealand [23-25], Taiwan [26], Turkey [27], and United Kingdom [28]). Three articles are elements of a series to summarize the literature on malignant wounds in a holistic configuration to assist with practice decisions [17-19]. Two articles lay emphasis on exploring patients' experiences of living with malignant wounds $[21,26]$. Five articles synthesize evidence of honey as topical treatments for wounds $[23-25,27,28]$. One article focuses on topical treatments for controlling odor in malignant wounds [20]. Of all 12 articles, only one specifically studied a particular group with breast cancer [21]. A global summary of the search results is presented in Table 1.

The information extracted from the review process reflects that the likelihood of malignant wound development in the breast cancer patients provides a multitude of opportunity for research and practice advancement in breast cancer wound management suitable with local Indonesian culture. The details are discussed below.

\section{Development of malignant wounds}

Malignant wounds in the most cases are developed through several mechanisms: (a) Metastatic growth of tumor cells from primary tumors, either local or distant, (b) primary cutaneous tumors, and (c) direct invasion by a primary tumor into skin structures $[17,26]$. In addition, malignant wounds have the ability to develop progressively and often enlarge within $24 \mathrm{hrs}$ which can cause massive cutaneous destruction and create ulcerating or proliferating ("fungating") appearance $[17,20,26]$. Moreover, even though every malignant tumor can metastasize to any region of the body, particular types of malignancies have a predilection for specific body sites. In women, for example, breast tumors commonly metastasize to the breast or chest wall [17].

\section{Key symptoms in malignant wounds}

Malignant wounds exemplify a range of symptoms that may present individually or collectively [20]. The major symptoms in malignant wounds discussed by most authors are as follows:

\section{Malodor}

Pungent odor results from the metabolic process of bacteria cultivating in the necrotic tissue (particularly anaerobic bacteria such as Bacteroides and Clostridium species) that release volatile putrid fatty acids which furthermore combine with metabolic products of other proteolytic bacteria $[18,20,22]$. Gas chromatography-mass spectrometry-olfactometry analysis of volatiles from fungating cancer wounds in a Japanese study resulted in the identification of dimethyl trisulfide as the source of malodor. Therefore, controlling the production of this compound could reduce the putrid smell from the wounds [30]. Malodor may also result from infection, hence systemic antibiotics are often administered [10].

Nurses often recognize malodor as one of the most difficult symptoms to control and the most distressing symptoms for patients, their careers, and families [18,26]. Especially in women, offensive odor decreases their sense of femininity, sexuality, and social intimacy as well as their body image and self-confidence [21,26]. Furthermore, malodor can be nauseating for both patients and family, thus reducing their appetite [31].

\section{Exudate}

Excessive exudate production in malignant wounds can arise from interrelated factors, including: (a) Fluid leakage from disordered and highly permeable tumor vasculature, (b) secretion of vascular permeability agents by tumor cells, (c) tissue catabolism by bacterial protease, and (d) Inflammatory processes associated with infection. In addition, exudates from chronic, non-healing wounds contain fewer growth factors, an increased level of proteolytic enzymes (matrix metalloprotease), and other corrosive substances that have potential to degrade the periwound tissue and expand the wound size [18]. Together with malodor, large quantities of exudate can lead to distress, social isolation and other psychosocial issues $[18,20,26]$.

\section{Pain}

A number of factors causing physical pain sensation in malignant wounds, including: Pressure from the tumor mass on other body structures, damage to nerves by the progressing tumors, exposure of dermal nerve endings, recurrent infections, swelling resulting from impaired capillary and lymphatic drainage, and wound care procedures. In addition to pain, pruritus may also need the same attention as pain because it can cause discomfort as this sensation utilizes similar conduction pathway with pain [18]

\section{Bleeding}

Bleeding and clotting irregularities in malignant wounds often occur due to abnormal vasculature in progressing tumors. Alteration in peritumor angiogenesis and coagulopathy may result in excess of circuitous; thin-walled vessels that are vulnerable to bleeding and resistant to hemostasis. Moreover, the delicateness of a malignant wound may be exacerbated in advance by systemic coagulopathy yielding from existing comorbidities or therapeutic regimens. Consequently, possible erosion of major blood vessels should be treated cautiously [18].

\section{Psychosocial issues}

Potential psychosocial issues associated with malignant wounds identified from literature are as follows: Social isolation, alteration in body image, stigma, existential issues related to imminent death and the search for meaning in life, and alteration in relationships and loss of personhood. Where malignant wounds are located in greatly visible (head and neck) or intimate (breast or perineum) body sites, these issues are prone to be multifaceted [18]. Interconnection between psychosocial issues and other key physical symptoms, predominantly offensive odor and heavy exudates were also discussed $[18,20,21,26]$.

\section{THE POTENTIALS OF HONEY IN MANAGING BREAST CANCER WOUNDS}

In general, the most articles reveal conventional modern dressings and several topical treatment products that have been widely applied in managing malignant wounds. For example, systemic and topical metronidazole, silver dressing, and activated charcoal have been utilized for managing malodor; hydrocolloids, foam, alginates, 
Table 1: Summary of journal articles informing the potentials of honey in managing breast cancer wounds

\begin{tabular}{|c|c|c|c|c|c|}
\hline Author(s) & $\begin{array}{l}\text { Country } \\
\text { (language) }\end{array}$ & Aim & Method & Findings & $\begin{array}{l}\text { Significance to } \\
\text { malignant wounds } \\
\text { management in breast } \\
\text { cancer patients }\end{array}$ \\
\hline [17] & $\begin{array}{l}\text { Australia } \\
\text { (English) }\end{array}$ & $\begin{array}{l}\text { To summarize } \\
\text { existing literature } \\
\text { on the epidemiology, } \\
\text { etiology, presentation, } \\
\text { and assessment of } \\
\text { malignant wounds } \\
\text { to inform practice } \\
\text { decisions }\end{array}$ & Literature review & $\begin{array}{l}\text { Undefined incidence rate of } \\
\text { malignant wounds } \\
\text { Breast tumors have metastasis } \\
\text { predilections to breast or chest } \\
\text { wall } \\
\text { Focus of assessment should } \\
\text { incorporate all domains of the } \\
\text { patient's experience of illness }\end{array}$ & $\begin{array}{l}\text { Provides a } \\
\text { comprehensive guideline } \\
\text { for malignant wound } \\
\text { assessment in breast } \\
\text { cancer patients }\end{array}$ \\
\hline [18] & $\begin{array}{l}\text { Australia } \\
\text { (English) }\end{array}$ & $\begin{array}{l}\text { To summarize } \\
\text { existing literature on } \\
\text { the key symptoms of } \\
\text { malignant wounds } \\
\text { to inform practice } \\
\text { decisions }\end{array}$ & Literature review & $\begin{array}{l}\text { Key symptoms include physical } \\
\text { symptoms (malodor, exudates, } \\
\text { pain, and bleeding) and } \\
\text { psychosocial symptoms } \\
\text { Malodor was the most } \\
\text { distressing symptom and } \\
\text { the most difficult to manage. } \\
\text { Heavy exudates, pain, and } \\
\text { bleeding should also be the } \\
\text { center of attention }\end{array}$ & $\begin{array}{l}\text { Needs further } \\
\text { investigation on } \\
\text { particular psychosocial } \\
\text { issues related to } \\
\text { malignant wounds in } \\
\text { breast cancer patients }\end{array}$ \\
\hline [19] & $\begin{array}{l}\text { Australia } \\
\text { (English) }\end{array}$ & $\begin{array}{l}\text { To summarize } \\
\text { existing literature on } \\
\text { the management of } \\
\text { malignant wounds } \\
\text { to inform practice } \\
\text { decisions }\end{array}$ & Literature review & $\begin{array}{l}\text { Healing of malignant wounds } \\
\text { is not a realistic goal } \\
\text { Management of malignant } \\
\text { wounds best provided through } \\
\text { a multidisciplinary approach } \\
\text { Inter-relatedness of physical } \\
\text { and psychological domains }\end{array}$ & $\begin{array}{l}\text { The key of successful } \\
\text { management of malignant } \\
\text { wounds is comprehensive } \\
\text { and individualized } \\
\text { assessment } \\
\text { Needs further research } \\
\text { in management of } \\
\text { malignant wounds in } \\
\text { breast cancer patients } \\
\text { as most of available } \\
\text { literature is based on } \\
\text { general chronic wounds } \\
\text { Less robust designs } \\
\text { such as multiple case } \\
\text { studies may provide the } \\
\text { highest level evidence } \\
\text { because undertaking } \\
\text { RCTs on individuals with } \\
\text { unstable condition such } \\
\text { as malignant wounds } \\
\text { is difficult, especially in } \\
\text { controlling variables }\end{array}$ \\
\hline [20] & $\begin{array}{l}\text { Brazil } \\
\text { (English) }\end{array}$ & $\begin{array}{l}\text { To collect evidence } \\
\text { about topical } \\
\text { treatments to control } \\
\text { the odor of malignant } \\
\text { wounds }\end{array}$ & Systematic review & $\begin{array}{l}20 \text { studies were reviewed, } \\
7 \text { were clinical trials, } 5 \text { were } \\
\text { case series, and } 8 \text { were case } \\
\text { studies } \\
11 \text { topical treatments were } \\
\text { identified, three topical } \\
\text { treatments (Mesalt }{ }^{\circledR} \text {, activated } \\
\text { carbon and curcumin) were } \\
\text { categorized as moderate } \\
\text { evidence }\end{array}$ & $\begin{array}{l}\text { Needs development } \\
\text { for innovations in } \\
\text { managements of } \\
\text { malignant wounds in } \\
\text { developing countries } \\
\text { as Mesalt }{ }^{\circledR} \text { dressing is } \\
\text { not available in many } \\
\text { countries, activated } \\
\text { carbon dressings are } \\
\text { still expensive, and } \\
\text { curcumin ointment is a } \\
\text { new practice that is not } \\
\text { available commercially }\end{array}$ \\
\hline [21] & $\begin{array}{l}\text { Denmark } \\
\text { (English) }\end{array}$ & $\begin{array}{l}\text { To investigate the } \\
\text { way malignant } \\
\text { fungating wounds } \\
\text { affect femininity, } \\
\text { sexuality, and daily } \\
\text { life in women with } \\
\text { progressive breast } \\
\text { cancer }\end{array}$ & Exploratory study & $\begin{array}{l}\text { Malodorous and heavy exuding } \\
\text { wounds trigger anxiety about } \\
\text { leakage, make women avoid } \\
\text { wearing feminine attire and } \\
\text { moving toward physical } \\
\text { intimacy and sexual activity } \\
\text { The use of modern wound } \\
\text { care products improved the } \\
\text { experience of comfort and } \\
\text { sense of and freedom }\end{array}$ & $\begin{array}{l}\text { Needs for standardized } \\
\text { methods of practice } \\
\text { for care of malignant } \\
\text { wounds in women with } \\
\text { breast cancer }\end{array}$ \\
\hline
\end{tabular}


Table 1: (Continued)

\begin{tabular}{|c|c|c|c|c|c|}
\hline Author(s) & $\begin{array}{l}\text { Country } \\
\text { (language) }\end{array}$ & Aim & Method & Findings & $\begin{array}{l}\text { Significance to } \\
\text { malignant wounds } \\
\text { management in breast } \\
\text { cancer patients }\end{array}$ \\
\hline [22] & $\begin{array}{l}\text { Denmark } \\
\text { (English) }\end{array}$ & $\begin{array}{l}\text { To compare the effect } \\
\text { of honey-coated } \\
\text { and silver-coated } \\
\text { dressings on } \\
\text { the qualitative } \\
\text { bacteriology in } \\
\text { malignant wounds }\end{array}$ & $\begin{array}{l}\text { Randomized, controlled } \\
\text { clinical study (N=67: } \\
\text { Group A - Manuka } \\
\text { honey dressing; } \\
\text { N=34: Group B - Silver } \\
\text { dressing; N=33: Over a } \\
\text { 4-week period) }\end{array}$ & $\begin{array}{l}\text { The majority of the patients } \\
\text { were women with breast } \\
\text { cancer } \\
\text { Almost all wounds contained } \\
\text { at least one type of pathogen } \\
\text { The qualitative } \\
\text { bacteriological did not differ } \\
\text { over time or between the two } \\
\text { dressings }\end{array}$ & $\begin{array}{l}\text { Swab cultures of } \\
\text { malignant wounds } \\
\text { should not be routinely } \\
\text { performed and the } \\
\text { potential antibacterial } \\
\text { effect of the dressings } \\
\text { used could not be } \\
\text { confirmed in this patient } \\
\text { population }\end{array}$ \\
\hline [23] & $\begin{array}{l}\text { New Zealand } \\
\text { (English) }\end{array}$ & $\begin{array}{l}\text { To summarize } \\
\text { published clinical } \\
\text { usage of honey }\end{array}$ & Review & $\begin{array}{l}\text { Findings from } 17 \text { RCTs, } \\
5 \text { clinical trials, large amount } \\
\text { of case studies, and } 16 \text { trials on } \\
\text { experimental animals showed } \\
\text { that honey give good results } \\
\text { on a very wide range of types } \\
\text { of wounds } \\
\text { Laboratory studies found } \\
\text { that honey stimulates } \\
\text { cytokines production } \\
\text { and has antibacterial } \\
\text { potency (especially } \\
\text { Leptospermum honey) }\end{array}$ & $\begin{array}{l}\text { Honey (especially } \\
\text { Leptospermum honey) } \\
\text { has potential benefits in } \\
\text { malignant wound care } \\
\text { due to its bioactivities }\end{array}$ \\
\hline [24] & $\begin{array}{l}\text { New Zealand } \\
\text { (English) }\end{array}$ & $\begin{array}{l}\text { To determine the use } \\
\text { of honey in increasing } \\
\text { the rate of healing } \\
\text { in various acute and } \\
\text { chronic wounds }\end{array}$ & Review & $\begin{array}{l}19 \text { trials (randomized and } \\
\text { quasi randomized) were } \\
\text { reviewed } \\
\text { Honey may improve healing } \\
\text { times in mild and moderate } \\
\text { superficial and partial } \\
\text { thickness burns compared } \\
\text { with some conventional } \\
\text { dressings } \\
\text { Honey dressings as adjuvant } \\
\text { to compression do not } \\
\text { significantly increase healing } \\
\text { in leg ulcers }\end{array}$ & $\begin{array}{l}\text { There was insufficient } \\
\text { evidence to guide clinical } \\
\text { practice in malignant } \\
\text { wound management } \\
\text { Needs further } \\
\text { investigation to } \\
\text { determine the benefit of } \\
\text { honey in breast cancer } \\
\text { wounds }\end{array}$ \\
\hline [25] & $\begin{array}{l}\text { New Zealand } \\
\text { (English) }\end{array}$ & $\begin{array}{l}\text { To describe honey } \\
\text { as a biologic wound } \\
\text { dressing }\end{array}$ & Review & $\begin{array}{l}\text { Honey has a broad-spectrum } \\
\text { antibacterial activity, but there } \\
\text { is much variation in potency } \\
\text { between different honeys } \\
\text { There is good evidence } \\
\text { showing that honey also } \\
\text { possesses bioactivities } \\
\text { that stimulate the immune } \\
\text { response (thus promoting } \\
\text { the growth of tissues for } \\
\text { wound repair), suppress } \\
\text { inflammation, and bring } \\
\text { about rapid autolytic } \\
\text { debridement } \\
\text { Each of the } \\
\text { healing-promoting activities } \\
\text { can be found separately } \\
\text { in most pharmaceutical } \\
\text { products, but in honey they } \\
\text { are all present and work } \\
\text { together synergistically to } \\
\text { enhance the wound healing } \\
\text { process }\end{array}$ & $\begin{array}{l}\text { Needs further study } \\
\text { on the bioactive and } \\
\text { physical properties of } \\
\text { local Indonesian honeys, } \\
\text { especially for managing } \\
\text { breast cancer wounds }\end{array}$ \\
\hline
\end{tabular}


Table 1: (Continued)

\begin{tabular}{|c|c|c|c|c|c|}
\hline Author(s) & $\begin{array}{l}\text { Country } \\
\text { (language) }\end{array}$ & Aim & Method & Findings & $\begin{array}{l}\text { Significance to } \\
\text { malignant wounds } \\
\text { management in breast } \\
\text { cancer patients }\end{array}$ \\
\hline [26] & $\begin{array}{l}\text { Taiwan } \\
\text { (English) }\end{array}$ & $\begin{array}{l}\text { To explore the } \\
\text { experience of cancer } \\
\text { patients living with } \\
\text { malignant fungating } \\
\text { wounds }\end{array}$ & Exploratory study & $\begin{array}{l}\text { Five key themes were } \\
\text { identified: "Declining physical } \\
\text { well-being"; "wound related } \\
\text { stigma"; "need for expert } \\
\text { help"; "strategies in wound } \\
\text { management"; and "living } \\
\text { positively with the wound" } \\
\text { Participants were able to live } \\
\text { more positively with their } \\
\text { wounds after receiving wound } \\
\text { care advice, appropriate } \\
\text { dressings, and support for } \\
\text { self-care }\end{array}$ & $\begin{array}{l}\text { Helps to guide nursing } \\
\text { practice by giving } \\
\text { understanding the } \\
\text { meaning of a malignant } \\
\text { wound to cancer patients } \\
\text { and its influence to their } \\
\text { lives }\end{array}$ \\
\hline [27] & $\begin{array}{l}\text { Turkey } \\
\text { (English) }\end{array}$ & $\begin{array}{l}\text { To evaluate the } \\
\text { effects of three types } \\
\text { of honey (chestnut, } \\
\text { blossom, and } \\
\text { rhododendron) } \\
\text { on the healing of } \\
\text { full-thickness wounds }\end{array}$ & $\begin{array}{l}\text { Experimental (involving } \\
24 \text { New Zealand female } \\
\text { rabbits) }\end{array}$ & $\begin{array}{l}\text { A week after the wounds } \\
\text { were created, the formation } \\
\text { of granulation tissue, } \\
\text { epithelization, angiogenesis } \\
\text { and fibroplasia levels } \\
\text { increased in the honey-treated } \\
\text { groups ( }<<0.05 \text { ) } \\
\text { No statistical difference } \\
\text { between the three types of } \\
\text { honey in the healing process }\end{array}$ & $\begin{array}{l}\text { Honey accelerates the } \\
\text { inflammatory reaction } \\
\text { and initiates healing } \\
\text { since the initiation of } \\
\text { the treatment process } \\
\text { of acute wounds. The } \\
\text { benefits of honey for } \\
\text { treating malignant } \\
\text { wounds, especially in } \\
\text { breast cancer patients } \\
\text { need to be investigated }\end{array}$ \\
\hline [28] & $\begin{array}{l}\text { United } \\
\text { Kingdom } \\
\text { (English) }\end{array}$ & $\begin{array}{l}\text { To synthesize } \\
\text { evidence regarding } \\
\text { honey's role in health } \\
\text { care and identify } \\
\text { further specific } \\
\text { application of honey } \\
\text { in cancer care }\end{array}$ & Systematic review & $\begin{array}{l}43 \text { studies were reviewed, only } \\
5 \text { studies related to cancer } \\
\text { Studies were generally } \\
\text { poor in quality because of } \\
\text { small sample size, lack of } \\
\text { randomization, and absence of } \\
\text { blinding } \\
\text { Honey was found to be } \\
\text { a suitable alternative for } \\
\text { treating xerostomia, mucositis, } \\
\text { malignant ulcers and infected } \\
\text { lesions in pediatric cancer } \\
\text { patients }\end{array}$ & $\begin{array}{l}\text { In the oncology setting, } \\
\text { honey may be useful } \\
\text { for treating fungating } \\
\text { wounds and surgical } \\
\text { wounds following the } \\
\text { removal of tumors }\end{array}$ \\
\hline
\end{tabular}

RCT: Randomized control trial

and silicone dressings have been used to manage exudates; topical analgesia for managing pain; and hemostatic alginates for treating bleeding [19-22,26]. Two recent emerging treatments have also been reported to be effective (Miltefosine-a topical cytostatic; and electrochemotherapy). However, many modern dressing products are expensive, so not all patients can afford the cost, especially if they live in countries with cost containment issues in health care. Thus, providing alternative options that are acceptable to the patients' requirements is important [19].

Many alternative methods for managing malignant wounds were discussed in literature with very few of those supported by robust evidence $[15,19,20]$. One of the alternative methods that have been attracting interest to be used as wound dressing is honey [11,23,25].

Evidently, a large number of publications on laboratory studies showing that honey has a number of properties (physical and bioactive) that are beneficial in managing various wounds, including: Acidic (pH ranging from 3.2 to 4.5, can inhibit bacterial growth); high sugar content (osmotic effect, can draw exudate); contains an enzyme (glucose-oxidase, stimulates release of hydrogen-peroxide to function as antibacterial agent); stimulates release of cytokines and interleukins to promote tissue repair; and some types of honey (particularly
Leptospermum/Manuka honey) have phytochemical components that maintain antibacterial activity $[23-25,27,28]$. Clinical trials have also shown that honey is a good alternative to surgical debridement possibly owing to its ability to increase plasmin activity; an enzyme that specifically digests fibrin (fibrin attaches slough to the wound surface) but does not digest the collagen matrix needed for tissue repair [25]. Moreover, a study reported that the use of honey as a single treatment had rapid cleansing and deodorizing action within $24 \mathrm{hrs}$, particularly on fungating (malignant) wounds. It also reduced inflammation and exudate levels [23]. Nonetheless, the potential of honey in treating pain and bleeding in malignant wounds was not extensively discussed in the reviewed articles.

\section{IMPLICATIONS FOR PRACTICE, FURTHER RESEARCH AND POLICY}

Multidisciplinary team approach is the paramount strategy in managing care for malignant wounds as the intricate nature of malignant wounds demands a realistic goal. Therefore, practices in malignant wound management will differ from those utilized in other settings, which aim toward healing $[19,26]$. It is also vital to perform an ongoing and comprehensive assessment which incorporates all domains of the patient's illness experience as an essential key aspect in managing malignant wound effectively $[17,18]$. 
Some articles point out that managing physical symptoms will alleviate psychosocial symptoms, such as altered body image and social isolation, especially with women with malignant breast wounds $[19,21,26]$. In addition, treating the malignancies (e.g., chemotherapy, radiotherapy, hormone therapy, laser therapy, cryotherapy, and/or surgery) was reported to have significant support besides wound care [19]. Besides treating the underlying pathology, addressing nutrition and other supportive aspects of care should never be overlooked [32]. Policy needs to address the resource allocations to ensure the provision of the supportive care during treatment for breast cancer, especially for a low- and middle-income country like Indonesia [33]. Calvary Hospital, New York introduced an approach to palliative wound care in an inpatient, home, and outpatient setting: S - Stabilizing the wound; P - Preventing new wounds; E - Eliminate odor; C - Control pain; I - Infection prophylaxis; A - Advanced, absorbent wound dressing; L - Lessen dressing changes (SPECIAL) [32].

It is difficult to obtain robust evidence through randomizedcontrolled trials in malignant wounds because reaching control in the circumstances of unstable or terminal disease is almost unfeasible. Less strong evidence from existing multiple case study designs should be acceptable for guiding practice in managing malignant wounds [19]. However, further research is needed to investigate the use of honey as wound dressings to manage malodor, exudates, pain, and bleeding, particularly in breast cancer wounds. As various types of honey available in Indonesia may have different properties with the other clinically tested honeys (e.g., Medihoney ${ }^{\mathrm{TM}}[29,33,34]$ ), it would be beneficial to study Indonesian's native honeys' properties that may have potentials to be utilized in breast cancer wound management. In addition, safety measures should also be incorporated in the utilization of new evidence for practice.

\section{CONCLUSION}

The use of honey for managing malignant wounds could be a favorable practice innovation concerning the health-care cost containment issues and limited resources. Nevertheless, extended research is needed to investigate the use of honey for treating pain and bleeding in malignant wounds so that the value of honey in this particular condition can be strengthened.

\section{REFERENCES}

1. Youlden DR, Cramb SM, Yip CH, Baade PD. Incidence and mortality of female breast cancer in the Asia-Pacific region. Cancer Biol Med 2014;11(2):101-15.

2. Yip C. Breast cancer in Asia. In: Verma M, editor. Cancer Epidemiology. New York, USA: Humana Press; 2009. p. 51-64. Available from: http:// www.springerlink.com/index/10.1007/978-1-59745-416-2. [Last cited on 2016 Sep 30]

3. Effendy C. The Quality of Palliative Care for Patients with Cancer in Indonesia. Netherlands: Radboud University Nijmegen; 2016.

4. Ferris FD, Al Khateib AA, Fromantin I, Hoplamazian L, Hurd T, Krasner DL, et al. Palliative wound care: Managing chronic wounds across life's continuum: A consensus statement from the International Palliative Wound Care Initiative. J Palliat Med 2007;10(1):37-9.

5. Krishnasamy M. Wound management. In: Corner J, Bailey C, editors. Cancer Nursing: Care in Context. Carlton, Victoria: Blackwell Science Ltd.; 2008.

6. Naylor W. Malignant wounds. In: O'Connor M, Aranda S, editors. Palliative Care Nursing: A Guide to Practice. Melbourne, Australia: Ausmed Publications Pty Ltd.; 2004. p. 200-13.

7. Clark J. Metronidazole gel in managing malodorous fungating wounds. Br J Nurs 2002;11 Suppl: S54-60.

8. Ayello EA, Schank JE. Ulcerative lesions. In: Kuebler KK, editor. Palliative and End-of-Life Care: Clinical Practice Guidelines. $2^{\text {nd }}$ ed. St. Louis, Missouri: Elsevier Health Sciences, Inc.; 2007. p. 519-36.

9. Jackson S. Palliative care issues for people with cancer. In: Stevens E, Jackson S, Milligan S, editors. Palliative Nursing: Across the Spectrum of Care. West Sussex: United Kingdom: Blackwell Publishing Ltd.;
2009. p. 220-40

10. Benbow M. Fungating malignant wounds and their management. J Community Nurs 2009;23(11):12-8.

11. Dente KM. Alternative Treatments for Wounds: Leeches, Maggots, and Bees; 2007. Available from: http://www.medscape.com/ viewarticle/563656. [Last cited on 2016 Sep 30].

12. Challinor JM, Galassi AL, Al-Ruzzieh MA, Bigirimana JB, Buswell L, So WK, et al. Nursing's potential to address the growing cancer burden in low-and middle-income countries. J Glob Oncol 2016;2(3):154-63.

13. Rahayuwati L, Ibrahim K, Mardiah W. Health seeking behavior on breast cancer therapies: Patients' versus providers' views. J Community Public Health Nurs 2016;2(3):2-6.

14. McManus J. Principles of skin and wound care: The palliative approach. Wound Types 2009;5(1):1-47.

15. Haesler E, Watts R, Rice J, Carville K, Haesler E, Watts R, et al. Local resource botanicals used in wound care. Wound Pract Res 2016;24(2):84-90.

16. Morris C. The use of honey in wound care and the Mesitran product range. Wounds UK 2008;4(3):3-5.

17. Alexander S. Malignant fungating wounds: Epidemiology, aetiology, presentation and assessment. J Wound Care 2009;18(7):273-80.

18. Alexander S. Malignant fungating wounds: Key symptoms and psychosocial. J Wound Care 2009;18(8):325-9.

19. Alexander S. Malignant fungating wounds: Managing malodour, exudate, pain, bleeding, and psychosocial issues. J Wound Care 2009;18(9):418-25.

20. da Costa Santos CM, de Mattos Pimenta CA, Nobre MR. A systematic review of topical treatments to control the odor of malignant fungating wounds. J Pain Symptom Manage 2010;39(6):1065-76.

21. Lund-Nielsen B, Muller K, Adamsen L. Malignant wounds in women with breast cancer: Feminine and sexual perspectives. J Clin Nurs 2005;14(1):56-64.

22. Lund-Nielsen B, Adamsen L, Gottrup F, Rorth M, Tolver A, Kolmos HJ. Qualitative bacteriology in malignant wounds-a prospective, randomized, clinical study to compare the effect of honey and silver dressings. Ostomy Wound Manag 2011;57(7):28-36.

23. Molan PC. The evidence supporting the use of honey as a wound dressing. Int J Low Extrem Wounds 2006;5(1):40-54.

24. Jull AB, Rodgers A, Walker N. Honey as a topical treatment for wounds. Cochrane Libr 2009;4:1-47.

25. Molan PC, Rhodes T. Honey: A biologic wound dressing. Wounds 2015;7(6):141-51. Available from: http://www.woundsresearch. com/article/honey-biologic-wound-dressing. [Last cited on 2016 Sep 30].

26. Lo SF, Hu WY, Hayter M, Chang SC, Hsu MY, Wu LY. Experiences of living with a malignant fungating wound: A qualitative study. J Clin Nurs 2008;17(20):2699-708.

27. Nisbet HO, Nisbet C, Yarim M, Guler A, Ozak A. Effects of three types of honey on cutaneous wound healing. Wounds 2010;22(11):275-83.

28. Bardy J, Slevin NJ, Mais KL, Molassiotis A. A systematic review of honey uses and its potential value within oncology care. J Clin Nurs 2008;17(19):2604-23.

29. Cooper RA, Jenkins L. A comparison between medical grade honey and table honeys in relation to antimicrobial efficacy. Wounds 2009;21(2):29-36. Available from: http://www.woundsresearch.com. [Last cited on 2016 Sep 30].

30. Shirasu M, Nagai S, Hayashi R, Ochiai A, Touhara K. Dimethyl trisulfide as a characteristic odor associated with fungating cancer wounds. Biosci Biotechnol Biochem 2009;73(9):2117-20.

31. Lloyd H. Management of bleeding and malodour. J Community Nurs 2008;22(8-9):28-34

32. Alvarez OM, Kalinski C, Nusbaum J, Hernandez L, Pappous E, Kyriannis $\mathrm{C}$, et al. Incorporating wound healing strategies to improve palliation (symptom management) in patients with chronic wounds. J Palliat Med 2007;10(5):1161-89.

33. Cardoso F, Bese N, Distelhorst SR, Bevilacqua JL, Ginsburg O, Grunberg SM, et al. Supportive care during treatment for breast cancer: Resource allocations in low-and middle-income countries. A Breast Health Global Initiative 2013 consensus statement. Breast 2013;22(5):593-605.

34. Simon A, Traynor K, Santos K, Blaser G, Bode U, Molan P. Medical honey for wound care - Still the "latest resort"? Evid Based Complement Alternat Med 2009;6(2):165-73. 